\author{
JAROStAW OCH \\ Uniwersytet Gdański \\ ORCID: https://orcid.org/0000-0003-0771-2732
}

\title{
Wielowymiarowość migracji jako zjawiska badawczego
}

\section{Multidimensionality of migration as a research phenomenon}

\section{Abstract}

Acting in the area of migration, research interest of many scientific disciplines are the subject of interdisciplinary research, as well as gathered in a circle one discipline. The complexity of the concept of migration results in many ways of its classification; often diverse perspective to look at the processes of displacement reveals the complex nature of the criteria for classification, although sometimes it turns out that they do not cover all the ways of perceiving and analyzing. Migration as a social phenomenon have been and is shaped by diverse conglomeration of contemporary factors and conditions.

Keywords: Multidimensionality, migration, analyzing, classification

\section{Многомерность миграции как исследовательского явления}

\section{Аннотация}

Миграции, представляя собой область исследования ряда научных дисциплин, стали как междисциплинарным предметом изучения, так и сосредоточенным 
в кругу одной дисциплины. Сложность понятия миграции приводит к нескольким способам его классификации; нередко разнообразные взгляды на процессы перемещения показывают трудности критериев классификации, хотя иногда оказывается, что они не исчерпывают всех видов восприятия и анализирования миграции. Миграции, как социальное явление, формировались всегда и сейчас как конгломерат разнообразных факторов и условий.

Ключевые слова: многомерность, миграция, анализ, классификация

\section{Wprowadzenie}

T

rozważaniach teoretycznych i analizach dotyczących zjawiska migracji dostrzega się współcześnie wielowymiarowość tego zjawiska (Clarence, 1984; Hoffman-Novotny, 1970; Castels i Kosack, 1973; Leoński, 1979; Kubiak, 1980; Okólski, 1992; Knopek, 1998, Świętochowska, 2007). Ujawnia się to zarówno w problemach w definiowaniu migracji, jak również w kwestii wskazywania jej determinantów i sposobów klasyfikacji. Jeden z najwybitniejszych teoretyków problematyki migracji R. Pryor wskazywał, iż „poszukiwanie jednej teorii migracji to [...] pogoń za utopią” (Pryor, 1975).

Główną tezą przyjętą w niniejszym tekście jest twierdzenie, iż migracje stanowiąc obszar zainteresowania badawczego wielu dyscyplin naukowych - stają się przedmiotem badań interdyscyplinarnych, jak też skupionych w kręgu jednej dyscypliny. Najczęściej przemieszczenia ludności stanowią istotne zjawisko badawcze z punktu widzenia: 1) ekonomii, ponieważ większość zachowań migracyjnych ma podtekst zarobkowy, a mobilność siły roboczej wpływa zarówno na aktywność ekonomiczną zaangażowanych w nią osób, jak również ma określone konsekwencje gospodarcze; 2) socjologii, gdyż migracje mają najczęściej charakter masowy, odbywają się w kontekście społecznym i tworzą nowe struktury społeczne; 3) psychologii, ponieważ stanowią efekt określonego procesu decyzyjnego, a sama migracja skutkuje nierzadko przemianami w sferze tożsamości i świadomości; 4) politologii, bo wiążą się z przekraczaniem granic jednostek terytorialnych i granic państwowych oraz wpływają na sytuację polityczną zarówno obszarów wysyłających, jak też i docelowych; 5) historii, gdyż przemieszczenia ludności kształtowały obraz minionego i obecnego świata (Górny i Kaczmarzyk, 2003). 
W artykule skoncentrowano się na próbie odpowiedzi na następujące pytania badawcze: 1) jakie czynniki determinują i warunkują współcześnie procesy globalnych migracji; 2) jakie kryteria typologiczne są najbardziej użyteczne w opisie i analizie współczesnych trendów migracyjnych; 3) jak kształtują się węzłowe aspekty i wymiary deskrypcji i analizy współczesnych trendów migracyjnych?

Ze względu na zróżnicowany charakter zjawiska migracji istotną rolę w próbie usystematyzowania wiedzy na jego temat oraz dokonania analizy zjawiska odgrywa kwestia jego definiowania oraz klasyfikowania. W najprostszym sposobie definiowania migracji ujmuje się ją jako „zjawisko przemieszczenia lub opuszczenia przez osobę danego miejsca $\mathrm{w}$ inny sposób niż urodzenie lub śmierć" (Lewis, 1982). Ten sposób definiowania nie zapewnia jednak szerokiej perspektywy spojrzenia na kwestie migracji i skutkuje potrzebą wypracowania podstawowych kryteriów jej klasyfikacji. Do najważniejszych zalicza się: 1) kryterium przestrzenne - ujmujące migracje jako proces przemieszczania na pewną odległość; 2) kryterium miejsca zamieszkania lub pobytu - nakazujące traktować migranta jako osobę zmieniającą miejsce zamieszkania; 3 ) kryterium czasu - pozwalające oddzielić migrantów od turystów; 4) kryterium aktywności - wskazujące na zmianę dotychczasowych form aktywności, będącą skutkiem migracji.

Złożoność pojęcia migracji skutkuje wieloma sposobami jego klasyfikowania; nierzadko zróżnicowana perspektywa spojrzenia na procesy przemieszczeń uwidacznia złożony charakter kryteriów klasyfikowania, choć czasem okazuje się, iż nie wyczerpują one wszystkich sposobów jej postrzegania i analizowania (Kraszewski, 2003; Górny i Wasilewski, 1988).

Istotnym uzupełnieniem rozważań dotyczących kwestii klasyfikacji migracji jest spostrzeżenie, że zjawisko przemieszczeń nie funkcjonuje jako wyalienowane z otaczającego go świata (politycznego, kulturowego, ekonomicznego, społecznego), lecz jest $\mathrm{z}$ nim w permanentnej interakcji. To zaś skutkuje trwałymi przekształceniami nie tylko w obrębie teoretycznych aspektów migracji, w tym sposobów jej klasyfikowania i definiowania, ale również praktyki funkcjonowania zjawiska. 


\section{Determinanty i wielowymiarowość migracji}

Migracje jako zjawiska społeczne kształtowane były i są współcześnie przez zróżnicowany konglomerat czynników i uwarunkowań. Wśród podstawowych wymienia się przede wszystkim takie, jak: rozwój struktury demograficznej kraju, sytuacja polityczno-społeczna, koniunktura gospodarcza, sytuacja osobista i rodzinna, względy religijne oraz narodowościowe.

Powody migracji wyznaczają często istotną rolę przy formułowaniu podstawowych wymiarów jej ujmowania i uznawane są za jeden $\mathrm{z}$ głównych kryteriów klasyfikacji. Równie ważnym czynnikiem ujmowanym w klasyfikacjach migracji jest kwestia ich postrzegania $\mathrm{w}$ wymiarze percepcji określonych dyscyplin naukowych.

Z socjologicznego punktu widzenia akcentuje się następujące typy migracji, uwzględniając (Dyoniziak i in., 1994; Richmond, 1994; Kubiak i Slany, 1999; Sztompka, 2002):

- zakres wolności decyzji migracyjnych - migracje dobrowolne i przymusowe; dobrowolne wynikają z suwerennej decyzji migranta, przymusowe uwarunkowane są czynnikami od migranta niezależnymi (np. decyzje władz państwowych o wysiedleniach ludności);

- czynniki i okoliczności sprawcze migracji - migracje spontaniczne i planowe; migracje spontaniczne wywołane są niezaplanowanymi wcześniej zdarzeniami i sytuacjami, planowe są konsekwencja wcześniej przyjętych algorytmów postępowania;

- przyczyny migracji - migracje zarobkowe, polityczne, innowacyjne, konserwatywne; migracje zarobkowe i ekonomiczne wydają się współcześnie najczęstszym motywem wychodźstwa, choć nie jedynym, migracje polityczne wynikają $\mathrm{z}$ różnie motywowanych decyzji podmiotów politycznych, migracje innowacyjne to wychodźstwo spowodowane podążaniem za rozwojem i zdobyczami nauki i techniki, które w kraju nie są dostępne i powszechne, migracje konserwatywne to wyjazdy z kraju spowodowane zbyt dużym ładunkiem liberalizmu obyczajowo-kulturowego, który nie dla wszystkich mieszkańców jest do zaakceptowania.

- status prawny migranta - emigranci legalni i nielegalni; migranci legalni uzyskują akceptację swego pobytu przez władze kraju emigracji, 
co nierzadko prowadzi do nadania obywatelstwa i pełni praw publicznych, migranci nielegalni to osoby nieakceptowane przez władze, skutkiem czego może nastąpić ich deportacja i kilkuletni zakaz wjazdu na terytorium państwa;

- liczbę osób wspólnie migrujących - migracje indywidualne, w grupach rodzinnych i podporządkowane; migracje indywidualne to wyjazdy jednoosobowe, alternatywą może być migracja członków rodziny (tzw. łańcuchowa) lub wynikająca z podporządkowania jednej osoby drugiej;

- czas trwania migracji - stałe, okresowe (sezonowe) i codzienne;

- terytorium docelowe - migracje wewnętrzne i zewnętrzne;

- charakter jednostki osiedleńczej - ze wsi do miast i odwrotnie, dokonywane między wsiami i miastami.

Geograficzny wymiar ujmowania migracji opiera się na podziale ze względu na ich kontekst (Maryański, 1966; Barbar, 1987; Długosz, 2000; Otok, 2002; Carlo, 2003; Fierli, 2003; Rykiel, 2006; Knopek, 2007):

- przyczynowy - migracje uzależnione od warunków ekonomicznych, politycznych oraz o innym uwarunkowaniu. Migracje ekonomiczne określa się mianem dobrowolnych, w których dominuje chęć polepszenia warunków egzystencji migranta; migracje polityczne wyznacza ich przymusowość (przesiedlenia ludności, ucieczki przed dyskryminacją, zmiany granic państwowych, konflikty etniczne i religijne). Do innych form migracji należą dobrowolne wędrówki o charakterze pozaekonomicznym, jak pielgrzymki religijne lub wyjazdy turystyczne;

- geograficzny - migracje międzypaństwowe (zewnętrzne) i wewnętrzne (krajowe). Wśród migracji międzypaństwowych dokonuje się nierzadko podziału na migracje zamorskie (międzykontynentalne) oraz kontynentalne;

- czasowy - migracje stałe, okresowe lub sezonowe. Migracjom stałym towarzyszy podjęcie decyzji o pozostaniu na wychodźstwie na zawsze lub brak wskazania czasowej perspektywy powrotu do kraju urodzenia; migracje okresowe determinowane są najczęściej przez przesłanki natury finansowej bądź rozwoju zawodowego i cywilizacyjnego jednostki; migracje sezonowe polegają na krótkotrwałym (kilka tygodni bądź kilka miesięcy) opuszczeniu kraju w celach zarobkowych lub edukacyjnych, są popularne głównie wśród młodzieży akademickiej; 
- osadniczy - migracje z miast do miast, z miast do wsi, ze wsi do miast i ze wsi do wsi. Podział ma głównie charakter teoretyczny, gdyż migracje $\mathrm{z}$ miast do wsi nie są tak częste (choć obserwuje się trend wzrostowy), jak migracje ze wsi do miast. Głównym czynnikiem sprawczym migracji tego typu są względy ekonomiczno-cywilizacyjne. Ucieczki ze wsi do miast to próba znalezienia pracy (środowisko uprzemysłowione) oraz zmiany na lepsze środowiska kulturowo-cywilizacyjnego.

W analizach politologicznych wskazuje się najczęściej na następujące kryteria migracji (Zolberg, 1989; Chodubski, 1992; 2006; Szydłowska-Cegłowa, 1992; Brzezinski, 1994; Haliżak i Kuźniar, 1994; Cesarz i Stadtmuller, 1998; Kukułka, 1997; Olszewski, 1997; Łoś- Nowak, 2000; Knopek, 2001; 2007; Piwnicki, 2007; Majewski, 2007: Świętochowska, 2007):

- dobrowolne, spontaniczne, planowe i przymusowe - w zależności od charakteru podejmowanych decyzji; migracje dobrowolne, planowe i spontaniczne stanowią konsekwencje suwerennych decyzji migrantów, zaś migracje przymusowe są konsekwencją zdarzeń i faktów od migrantów niezależnych; do kategorii przymusowych zalicza się: wydalenie, wypędzenie, repatriację, uchodźstwo, wysiedlenie, ewakuacje oraz deportację;

- zarobkowe, rodzinne, podporządkowane, demograficzne, matrymonialne, polityczne, religijne, narodowościowe, ekologiczne, zdrowotne i indywidualne - w zależności od powodów i przyczyn migracji; współcześnie obserwuje się zjawisko stopniowego zmniejszania natężenia migracji politycznych, religijnych, matrymonialnych na rzecz wzrostu poziomu natężenia migracji zarobkowych, zdrowotnych, ekologicznych oraz rodzinnych;

- stałe, sezonowe i okresowe - w zależności od czasu trwania migracji; ujawniającym się współcześnie trendem są migracje krótkotrwałe, których celem jest najczęściej nauka, zdobycie doświadczeń zawodowych oraz kwestie natury finansowej;

- wewnętrzne, zewnętrzne, kontynentalne, zamorskie, regionalne w zależności od swoistości geograficznej migracji;

- $\mathrm{z}$ miast do miast, $\mathrm{z}$ miast do wsi, ze wsi do wsi i ze wsi do miast w zależności od osadnictwa migracji; 
- legalne i nielegalne - w zależności od charakteru prawnego migracji, wyznaczanego regulacjami prawnymi krajów oraz możliwościami i potrzebami absorpcji ludności napływowej.

- emerytalne, masowe, konserwatywne, innowacyjne oraz mające charakter exodusu - w zależności od innych rodzajów migracji.

\section{Klasyfikacje migracji}

Zjawisko migracji klasyfikowane jest również według innych kryteriów, takich jak: przyczyny migracji, ich swoistość geograficzno-polityczna, czas trwania, charakter osadnictwa ludności migrującej w aspekcie miejsca wychodźstwa i miejsca osadnictwa oraz organizacja form migracji (Stępniak, 2001; Romaniszyn, 2003; Świętochowska, 2007; Piwnicki, 2007).

Migracje analizowane pod względem przyczyn wychodźstwa dzieli się na migracje powodowane warunkami ekonomiczno-finansowymi, politycznymi oraz względami osobistymi (Knopek, 2007; Kubiak, 1999). Do kategorii migracji motywowanych względami finansowymi zalicza się współcześnie większość przemieszczeń, jaka miała miejsce od zarania migracji do czasów współczesnych. Podstawowym czynnikiem wpływającym na decyzje migracyjne stają się oczekiwania, że wraz z migracją polepszeniu, a nierzadko radykalnemu odmienieniu, ulegną warunki codziennej egzystencji i bytowania. Migracje motywowane ekonomicznie zyskują na znaczeniu wraz z rozwojem ekonomiczno-gospodarczym współczesnego świata. Fakt ten powoduje, iż dywersyfikacji ulega poziom życia i egzystencji we współczesnych państwach, zmieniają się możliwości uzyskania atrakcyjnego zatrudnienia oraz samorealizacji zawodowej i społecznej.

Przekonanie, że większość państw słabo rozwiniętych nie będzie w stanie w najbliższej przyszłości zagwarantować odpowiedniego poziomu życia swoim mieszkańcom i rosnące jednocześnie aspiracje do pełnego uczestnictwa w ekspansji gospodarczej państw wysokorozwiniętych, działa bezsprzecznie jako czynnik mobilizujący do migracji. Jednocześnie odnotować należy, iż pojawiająca się recesja gospodarcza państw wysoko rozwiniętych stymulować będzie zaostrzanie polityki imigracyjnej, uszczelnianie granic i odsyłanie do państw wychodźstwa imigrantów nielegalnych. 
Do kategorii migracji uwarunkowanych politycznie zalicza się te przemieszczenia, które dyktowane są względami wyłącznie politycznymi (Muszyński, 2001). Migracje tego typu nabrały szczególnego znaczenia w XX wieku, kiedy masowymi stały się ucieczki ludności przed reżimami totalitarnymi, czystkami narodowościowymi oraz innymi formami dyskryminacji motywowanymi politycznie. Migracje polityczne przebiegają na zasadzie jednostronnego wysiedlenia ludności lub też jej dwustronnej wymiany międzypaństwowej, mogą mieć zarówno charakter ruchów masowych, jak również indywidualnych, przy czym nie zawsze charakter osadnictwa motywowanego względami politycznymi jest stały. Nierzadko po ustaniu politycznych przyczyn migracji zapada decyzja migrantów o powrocie do kraju wychodźstwa, choć zdarza się również, że względy rodzinne, finansowe oraz kulturowe powodują kontynuację pobytu poza miejscem urodzenia. Współcześnie w odniesieniu do migracji politycznych obserwuje się trend polegający na tym, że państwa niestabilne politycznie, nie zapewniające swoim obywatelom bezpieczeństwa, w których kryzysy stają się cechą immanentną, przekształcają się w państwa emigracyjne. Niektóre z nich całkowicie nawet rezygnują z barier i ograniczeń emigracyjnych, co jeszcze bardziej sprzyja wychodźstwu. W państwach zaś przyjmujących imigrantów coraz częściej zauważa się wzrost nastrojów ksenofobicznych, powstawanie organizacji i partii politycznych, tworzących ruchy sprzeciwu i walki z obcymi, a nierzadko społeczną akceptację dla przemocy ukierunkowanej na imigrantów. Zjawiska te dotyczą najczęściej krajów, w których migranci nie poddali się procesowi asymilacji i wyraziście demonstrują i znaczą swą odrębność i inność (przykładem jest odmienność wyznawców islamu w chrześcijańskiej Europie). Sytuacja ta prowadzi współcześnie do wyraźnego zmniejszenia poziomu stabilności politycznej i społecznej tych państw.

Cechą charakterystyczną migracji politycznych jest trudność w wyznaczeniu dokładnej i precyzyjnej granicy pomiędzy politycznymi i ekonomicznymi powodami migracji, gdyż wiek XX charakteryzował znaczący splot polityki i ekonomii, a wpływ obu dziedzin życia publicznego na siebie nawzajem był coraz większy i korelacja zachodząca miedzy nimi utrudniała dokładne rozgraniczenie tego, czy bardziej wpływa na politykę ekonomia, czy też decyzje ekonomiczne są motywowane politycznie (problem ten nie 
dotyczy jedynie krajów, w których nie funkcjonują mechanizmy gospodarki wolnorynkowej).

Wśród migracji ujmowanych w kontekście przyczyn wychodźstwa wskazuje się również na przemieszczenia motywowane względami pozaekonomiczno-politycznymi (Rajkiewicz, 2000). Do głównych kategorii tego typu migracji zalicza się: pielgrzymki religijne, wyjazdy turystyczno-urlopowe, wyjazdy edukacyjne, wyjazdy mające na celu podniesienie klasyfikacji zawodowych oraz wyjazdy wynikające $z$ chęcią łączenia rodzin lub pozostawania w stałym, bliskim związku z bliską sobie osobą.

Ze względu na geograficzny wymiar migracji wskazuje się na migracje międzypaństwowe (zewnętrzne) oraz wewnętrzne (Maryański, 1984). Pierwsze $\mathrm{z}$ nich charakteryzują przemieszczenia pomiędzy jednostkami politycznie suwerennymi, a więc na poziomie państw, drugie zaś mają charakter przemieszczeń wewnątrzpaństwowych. Wśród migracji międzypaństwowych szczególny charakter mają przemieszczenie zamorskie lub międzykontynentalne, czyli takie, które zachodzą pomiędzy państwami położonymi na różnych kontynentach lub przedzielonymi przez oceany $\mathrm{i}$ inne przestrzenie morskie. Klasycznym i najczęściej opisywanym przykładem takich migracji były migracje europejskie do państw położonych na obu kontynentach półkuli zachodniej, a także Australii.

W wymiarze czasu trwania migracji wskazuje się powszechnie na migracje stałe, okresowe lub sezonowe (Świętochowska, 2007). Istotą migracji stałych jest fakt, iż podejmując decyzję o wychodźstwie wyraża się chęć pozostania w kraju osiedlenia na stałe bądź też niemożliwy jest do określenia czasowy horyzont migracji. Migracje okresowe charakteryzują się założeniem, iż czas trwania migracji jest ściśle powiązany i skorelowany z czasem osiągnięcia celów, które założono w momencie podejmowania decyzji o przemieszczeniu. Najczęściej migracje okresowe powodowane są względami finansowymi i zarobkowymi. Po osiągnięciu celów migranci decydują się na powrót do kraju urodzenia, choć zdarza się nierzadko, że po pewnym czasie ponownie podejmują decyzje o czasowym wychodźstwie. W statystykach wielu państw ten typ migracji określany bywa mianem migracji sezonowej, a więc wyznaczanej rytmem życia przyrody i czasem zbiorów jej owoców. Migracje sezonowe charakteryzują się krótkim czasem ich trwania (kilka tygodni lub najwyżej kilka miesięcy) oraz faktem, iż przemieszczenia 
następują w obrębie państw sąsiedzkich lub położonych w bliskim sąsiedztwie. Najczęstszym sposobem zarobkowania stają się prace rolne, pomoc przy zbieraniu płodów rolnych oraz inne formy aktywności zależne od swoistości kraju osiedlenia. Do niedawna specyficzną, choć obecnie zanikającą formą sezonowych migracji, były wędrówki ludów koczowniczych, odbywające się w zależności od zmieniających się warunków wypasu stad. Obszarem tych przemieszczeń był Półwysep Arabski, Iran, Afganistan, niektóre okręgi zachodnich Chin oraz Afryki.

Innym sposobem ujmowania migracji w kontekście czasu ich trwania jest wskazywanie na cztery kategorie wyjazdów migracyjnych: 1) migracje najkrótsze - trwające nie dłużej niż 7 dni; 2) migracje trwające dłużej niż 7 dni, ale krócej niż 3 miesiące; 3) migracje trwające od 3 miesięcy do roku; 4) migracje najdłuższe - trwające ponad rok (Jaźwińska i in., 1997). Czasokres trwania migracji stanowi również kryterium klasyfikacyjne w świetle zaleceń ONZ i innych organizacji międzynarodowych. Według zaleceń powyższych gremiów migracja polega na przemieszczeniu się z jednego kraju do innego, przy czym nieobecność w pierwszym i pobyt w drugim kraju musi trwać nieprzerwanie określony czas. Jeśli trwa ponad rok, to występuje migracja długookresowa, jeśli zaś krócej, to jest to migracja krótkookresowa, która najczęściej definiowana jest jako trwająca nie mniej niż trzy miesiące. Migracje krótsze od trzymiesięcznych traktuje się jako mobilność w sensie turystycznym lub jako podróże służbowe, gdyż odbywając je nie realizuje się żadnej funkcji migracji (np. umowa o pracę za granicą, założenie rodziny, osiedlenie, przesiedlenie, itp.) (Jaźwińska i in., 1997).

W badaniach naukowych dotyczących czasowego wymiaru migracji zauważa się również masowość zjawiska wędrówek, które nie posiadają atrybutów typowych dla turystyki, ale też nie stanowią - ze względu na krótkotrwały charakter - migracji. Przemieszczenia tego typu zwykło określać się wahadłowymi, a w celu precyzyjnego ich ujęcia badawczego posłużono się następującą klasyfikacją: 1) migracje wahadłowe, incydentalne - migrant opuszcza kraj na dłużej niż trzy miesiące, ale jednokrotnie odbywa również migracje krótszą; 2) migracje wahadłowe, wielokrotne - migrant opuszcza kraj na dłużej niż trzy miesiące, ale wielokrotnie odbywa migracje krótsze; 3) migracje krótkookresowe, incydentalne - migrant opuszcza kraj jednokrotnie, a jego pobyt za granica trwa od trzech miesięcy do roku; 4) migracje 
krótkookresowe, wielokrotne - migrant opuszcza kraj wielokrotnie, a czas jednego z jego pobytów za granica trwa od 3 do 12 miesięcy; 5) migracje długookresowe - migrant odbywa migracje trwającą ponad 12 miesięcy; 6) migracja stała - migrant przebywa za granicą na stałe i nie jest członkiem gospodarstwa domowego, do którego należał w chwili migracji (Iglicka i in., 1996).

Kryterium wyznaczającym rodzaje migracji jest również charakter osadnictwa migrantów (Plich i Zgórniak, 1984). Do podstawowych rodzajów migracji zalicza się: migracje z miast do miast, z miast do wsi, ze wsi do miast oraz ze wsi do wsi. Nasilanie lub zmniejszanie fali osadnictwa uzależnione było od uwarunkowań politycznych, ekonomicznych i kulturowo-społecznych.

W Polsce powojennej najczęstszym modelem migracji były przemieszczenia ze wsi do miast. Wiązało się to z poszukiwaniem atrakcyjnego zatrudnienia, chęcią polepszenia socjalnych warunków egzystencji oraz możliwościami kontynuowania nauki i podnoszenia poziomu wykształcenia.

W Polsce współczesnej trend ten został zahamowany, a nawet odwrócony. Mieszkańcy dużych miast, spełnieni zawodowo i finansowo, poszukują coraz częściej ciszy i spokoju od wielkomiejskiego hałasu i podejmują decyzje o migracji z miasta na wieś. W niektórych środowiskach zawodowych staje się to nawet konieczne, by pozostawać w zgodzie z najnowszymi trendami społecznymi i kulturowymi. Migracje z miast na wieś, a więc z centrum na peryferie, są typowym efektem rozwoju gospodarczego państw i bogacenia się społeczeństw, a więc charakteryzują kraje wysoko uprzemysłowione. Do rzadkości należą natomiast migracje ze wsi na wieś. Głównymi ich powodami bywają kataklizmy, wojny, kryzysy gospodarcze oraz działania władz administracyjnych (np. Chiny podczas rewolucji kulturalnej).

Bardzo specyficznym typem migracji, ujmowanej w aspekcie charakteru osadnictwa, była migracja o charakterze kolonizacyjnym (Maryański, 1984). Najczęściej przebiegała w formie przemieszczeń ze wsi do wsi, choć zdarzały się odstępstwa od tej reguły. Istotą tej formy migracji było zasiedlanie obszarów wcześniej niezamieszkałych, bądź też słabo zasiedlonych przez człowieka. Klasycznym przykładem tego typu migracji były XIX-wieczne zasiedlenia pustynnych obszarów Ameryki Północnej i Południowej oraz Australii i Syberii. W zależności od kraju przemieszczenia te miały bądź to charakter migracji dobrowolnych, motywowanych najczęściej chęcią 
polepszenia sobie warunków życia, bądź też przymusowych, a więc takich, które były skutkiem decyzji politycznych. W przypadku ruchów przymusowych władze oczekiwały od migrantów ciężkiej pracy na rzecz rozwoju cywilizacyjnego obszarów, na które trafiali, oraz udziału w eksploatacji ważnych strategicznie i ekonomicznie bogactw naturalnych.

Współcześnie model migracji kolonizatorskiej zanika. Głównymi powodami takiego stanu rzeczy wydaje się być nie tylko ulęgająca sukcesywnemu zmniejszeniu dziewicza powierzchnia Ziemi, ale przede wszystkim istotnym hamulcem migracji kolonizatorskich są obecnie względy psychologiczno-społeczne. W świecie współczesnym dominuje bowiem migracja ukierunkowana miejsko, wiążąca się z bliskimi kontaktami interpersonalnymi z ludźmi, możliwością spełnień zawodowych i kulturalno-społecznych, a ludzi chętnych do spędzania życia w odległych, słabo cywilizowanych obszarach, nawet gdyby wiązało się z dostatkiem finansowym, jest niewielu. Do niedawna kolonizacja pionierska miała największe rozmiary w wewnętrznych obszarach Ameryki Południowej, zwłaszcza w Brazylii, rzadziej zaś występowała w niektórych rejonach Rosji (szczególnie na Syberii), Chin, Indonezji i Wietnamu.

Klasyfikując migrację w kontekście jej form organizacyjnych, wyróżnia się migracje żywiołowe oraz planowe (Knopek, 2007; Romaniszyn, 1999; OECD, 2007). Migracje żywiołowe charakteryzuje fakt szybkiego i spontanicznego podejmowania decyzji o migracji, u podstaw której leżą kwestie zagrożenia życia, zdrowia i stabilnej, spokojnej egzystencji. Przemieszczenia żywiołowe najczęściej powodowane są nagle zmieniającą się sytuacją życiową w otoczeniu człowieka, np. wybuch wojny, wulkanu, powódź, represje polityczne lub religijne. Niektóre zmiany są zależne od działań człowieka, inne zaś wynikają z praw natury, a więc nie sposób ich przewidzieć i im zapobiec. Współcześnie ten typ migracji skorelowany jest $\mathrm{z}$ wydarzeniami, które zniechęcają ludzi do życia w ich otoczeniu (np. żywiołowe przemieszczenia w obrębie USA po ataku terrorystycznym 11 września 2001 roku, ucieczki przed klęskami naturalnymi - huragany, powodzie). Migracje planowe wyznacza fakt szczegółowego przeanalizowania decyzji o migracji, uwzględnienia w procesie decyzyjnym wszystkich jej aspektów pozytywnych oraz negatywnych, starannego określenia oczekiwań i nadziei, jakie wiążą się z migracją, oraz szczegółowego zaplanowania nawet najdrobniejszych kwestii, wiążących 
się ze zmianą miejsca osiedlenia. Motywy migracji planowych mogą być różne (polityczne, religijne, kulturowe, ekonomiczne, zdrowotne, rozwoju intelektualnego i zawodowego), różny może być czas ich trwania, zróżnicowane mogą być też podmioty podejmujące decyzje o migracji - organy władzy państwowej (np. repatriacje) lub indywidualny obywatel (np. względy osobiste).

Współczesne ruchy migracyjne klasyfikować można również w oparciu o analizę ich aspektu prawnego (Michalska, 1982; Bierzanek i Symonides, 1992; Majewski, 2000; World Bank Group, 2018). Do podstawowych rodzajów migracji zalicza się w tym względzie migracje legalne, nielegalne oraz nieuregulowane. Istota migracji legalnych wiąże się ze zgodą czynników politycznych zarówno na wyjazd z kraju urodzenia, jak też na przyjęcie migrantów w kraju emigracji. Wydaje się, że migracje legalne są implikowane głównie decyzjami politycznymi, umożliwiającymi obywatelom państw przemieszczanie i zachodzi głównie w obszarze państw o demokratycznym modelu sprawowania władzy. Migracje nielegalne zaś to te, które odbywają się wbrew decyzjom władz państwa. Istotne jest wskazanie, iż decyzje władz uniemożliwiające migracje dotyczą zarówno kwestii opuszczenia granic kraju urodzenia, jak również kwestii umożliwienia osiedlenia w kraju emigracji. Cechą charakterystyczną migracji nielegalnych jest fakt, iż zachodzą one głównie pomiędzy krajami o odmiennych systemach ustrojowych, gospodarczych, a nierzadko też kulturowych. Niełatwa wydaje się kwestia interpretacji istoty migracji nieuregulowanych. Są to migracje postrzegane z jednej strony jako nielegalne, $z$ drugiej zaś jako tolerowane i akceptowane przez czynniki decyzyjne państw, pomiędzy ludnością, w których one zachodzą. Przykładem tego typu migracji były masowe wyjazdy z Polski lat 80 . na Zachód Europy (Świętochowska, 2007; Bahna, 2018). Choć oficjalnie czynniki rządowe ich nie popierały, to jednak w praktyce nierzadko do nich zachęcały i namawiały. Działanie te miały różne motywacje, ale najczęstszymi była chęć pozbycia się z kraju osób podejrzanych o niechęć do władzy oraz tych z pochodzeniem żydowskim lub niemieckim, a więc nieakceptowanym przez władze PRL-u.

W konstruowaniu sposobów klasyfikowania migracji nie poprzestaje się na jej ujmowaniu w oparciu o jeden wymiar, np. dyscypliny naukowej, czasoprzestrzeni lub obowiązującego prawa, lecz dostrzega się również potrzebę analizy wielowymiarowej i wieloaspektowej. Analiza taka daje możliwość 
wzbogacenia typologii migracje o kolejne, nierzadko nowatorskie sposoby jej ujmowania, a to z kolei poszerza i systematyzuje wiedzę na temat jej teorii i praktyki.

Dokonując analizy zjawiska migracji w kontekście kryteriów takich jak: czas jej trwania, związki migranta z gospodarstwem domowym pozostającym w kraju, typ aktywności ekonomicznej w czasie migracji oraz legalność pobytu, wyróżnić można następujące kategorie migracji: 1) migracje handlowe - migracje trwające krótko, charakteryzujące się ok. 2-3 tygodniowymi podróżami, których celem był zakup i sprzedaż towarów; 2) migracje osiedleńcze - formy migracji zmierzające do osiedlenia się na stałe w innym kraju; 3) migracje kontraktowe - legalne formy pobytu za granicą, głównie w obszarze pracy i nauki; 4) migracje czasowe - wyjazdy motywowane zarobkowo, charakteryzujące się pominięciem procedury legalizacyjnej; bez względu na czas ich trwania utrzymywane są bliskie kontakty $\mathrm{z}$ rodziną w kraju, a zdobyte środki finansowe służą zaspokajaniu jej potrzeb.

Odmienną perspektywę zainteresowania typami migracji zaprezentował jeden z pionierów badań migracyjnych W. Petersen. Uwzględniając czynnik motywacyjny i sprawczy przemieszczeń, wskazał na dwa zasadniczo odmienne typy migracji: innowacyjną i konserwatywną. Model migracji innowacyjnej opierał się na założeniu, że migracja stanowi element ludzkiego działania, zmierzającego do osiągnięcia czegoś nowego, lepszego. Migracja konserwatywna zaś była typem zachowań zmierzających do utrzymania status quo (np. chęć płacenia niskich podatków, ucieczka przed służbą wojskową). W obrębie powyższych modeli migracji Petersen wyodrębnił migracje szczegółowe, motywowane różnymi czynnikami sprawczymi (politycznymi, społecznymi, ekonomicznymi), których wspólnym wymiarem były bądź to zachowania o cechach innowacyjnych, bądź też konserwatywnych (Petersen, 1958).

\section{Podsumowanie}

Zaprezentowany w artykule selektywny przegląd badań uwidacznia konieczność wielokontekstowego, nawiązującego do zróżnicowanych teorii i interdyscyplinarnego oglądu przedmiotowych zjawisk. Współczesne ruchy migracyjne ujawniają socjologiczne, psychologiczne, ekonomiczne i polityczne 
uwarunkowania ich genezy i przebiegu, determinując interdyscyplinarną potrzebę ich oglądu i analiz. Współczesne badania oprócz tradycyjnych uwarunkowań ruchów migracyjnych wyrażają również nowe konteksty związane z przemianami klimatycznymi i technologicznymi, ułatwiającymi mobilność globalną oraz dostęp do zasobów ekonomicznych. W ślad za tym zmienia się także podłoże teoretyczne i perspektywa interpretacyjna, stanowiąca badawcze instrumentarium oglądu współczesnych migracji.

\section{DR JAROSŁAW OCH}

Instytut Politologii

Wydział Nauk Społecznych

Uniwersytet Gdański

ul. Jana Bażyńskiego 4, 80-309 Gdańsk

jaroslaw.och@ug.edu.pl

\section{Bibliografia}

Bahna, M. (2018). Predictions of Migration from the New Member States after Their Accession into the European Union: Successes and Failures, International Migration Review, 42(4), 844-860.

Barbarg, J. (1987). Geografia polityczna ogólna. Warszawa: PWN.

Bierzanek, R., Symonides, J. (1992). Prawo międzynarodowe publiczne. Warszawa: PWN. Brzeziński, Z. (1994). Bezład. Polityka światowa na progu XXI wieku. Warszawa: Editions Spotkania.

Carlo, J. (2003). Geopolityka. Wrocław: Ossolineum.

Castels, S., Kosack, G. (1973). Immigrant Workers and Class Structure in Western Europe. London: Oxford University Press.

Cesarz, Z., Stadtmuller, E. (1998). Problemy polityczne współczesnego świata. Wrocław: Wydawnictwo Uniwersytetu Wrocławskiego.

Chodubski, A. (1992). Emigracja jako zjawisko polityczne. Zeszyty Naukowe Uniwersytetu Gdańskiego. Nauki Polityczne, 11, 131-140.

Chodubski, A. (2006). Nowe formy migracji i typy imigrantów w Europie. W: E. Olszewski, M. Kuczerepa (red.). Wspólny obszar wolności, bezpieczeństwa i sprawiedliwości Unii Europejskiej a problemy migracji. Chełm: WSSMiKS.

Clarence, P.A. (1948). The Immigration Problem. New York: The H.W. Wilson company. Długosz, Z. (2000). Przemiany na mapie politycznej świata. Zamość: Centrum Badawczo-Szkoleniowe WSZiA.

Dyoniziak, R., Iwonicka, K., Karwińska, A., Pucek, Z. (1994). Społeczeństwo w procesie zmian. Zarys socjologii ogólnej. Kraków: Universitas. 
Fierli, I. (red.). (2003). Geografia gospodarcza świata. Warszawa: Polskie Wydawnictwo Ekonomiczne.

Górny, A., Kaczmarzyk, P. (2003). Uwarunkowania i mechanizmy migracji zarobkowych w świetle wybranych koncepcji teoretycznych. Prace Migracyjne, 49, 4-5.

Haliżak, E., Kuźniar, R. (red.). (1994). Stosunki międzynarodowe. Geneza, struktura, funkcjonowanie. Warszawa: Wydawnictwa Uniwersytetu Warszawskiego.

Hoffman-Novotny, H.J. (1970). Migration. Ein beitragzueiner Soziologischen Erklarung. Stuttgart: Enke.

Iglicka, K., Jaźwińska, E., Okólski, M. (1996). Współczesne migracje zagraniczne ludności Polski. Badania za pomocą podejścia etnosondażowego, Studia Demograficzne, 4. Jaźwińska, E., Łukowski, W., Okólski, M. (1997). Przyczyny i konsekwencje emigracji $z$ Polski. Prace Migracyjne, 7.

Knopek, J. (1998). W Europie przemian, konfliktów i kompromisów. Bydgoszcz: Dział Wydawnictw Wyższej Szkoły Pedagogicznej w Bydgoszczy.

Knopek, J. (2007). Migracje międzynarodowe jako przedmiot refleksji politologicznej. W: E. Polak, J. Leska-Ślęzak (red.). Procesy migracyjne w kontekście przemian kulturowo-cywilizacyjnych. Pelplin: Uniwersytet im. Adama Mickiewicza w Poznaniu. Knopek, J. (2001). Migracje Polaków do Afryki Północnej w XX wieku. Bydgoszcz: DiG. Kraszewski, P. (2003). Typologia migracji. W: W.J. Burszta, J. Serwański (red.). Migracje - Europa - Polska. Poznań.

Kubiak, H. (1980). Teoria, ideologia, polityka asymilacji. Szkic problemu. W: H. Kubiak, A.K. Paluch (red.). Założenia teorii asymilacji. Kraków: Ossolineum.

Kubiak, M., Slany, K. (1999). Migracje. W: Encyklopedia socjologii.t. 2. Warszawa: Oficyna Naukowa.

Kukułka, J. (1997). Historia współczesnych stosunków międzynarodowych 1945-1996. Warszawa: Wydawnictwo Naukowe Scholar.

Leoński, L. (1979). Zagadnienie migracji w polskiej myśli socjologicznej do 1939 roku. Poznań: Wydawnictwo Naukowe Uniwersytetu im. Adama Mickiewicza.

Lewis, G.J. (1982). Human Migration. A Geographical Perspective. London: Croom Helm.

Łoś-Nowak, T. (2000). Stosunki międzynarodowe: teorie, system, uczestnicy. Wrocław: Wydawnictwo Uniwersytetu Wrocławskiego.

Majewski, R. (2000). Przyczyny polskiego exodusu w latach osiemdziesiątych. W: E. Zamojski (red.). Migracje polityczne XX wieku, Migracje i społeczeństwo, 101-108.

Majewski, R. (2007). Zjawisko emigracji jako przejaw współczesnych przemian globalnych. W: E. Polak, J.Leska-Ślęzak (red.). Procesy migracyjne $w$ kontekście przemian kulturowo-cywilizacyjnych. Pelplin: Wydawinctwo Bernardinum, 223-232.

Marszałek-Kawa, J., Plecka, D., Hołub, A. (red.). (2018). Social Security. Selected Aspects. Toruń: Wydawnictwo Adam Marszałek.

Maryański, A. (1984). Migracje w świecie. Warszawa: PWN.

Maryański, A. (1996). Wspótczesne wędrówki ludów. Zarys geografii migracji. Wrocław [i in.]: Zakład Narodowy im. Ossolińskich.

Michalska, A. (1982). Prawa człowieka w systemie norm międzynarodowych. Warszawa: PWN.

Muszyński, J. (2001). Megatrendy a polityka. Wrocław: alta 2. 
Okólski, M. (1992). Migratory Movements from Countries of Central and Eastern Europe. W: People on The Move. New Migration Flows in Europe. Strasbourg: Council of Europe.

Olszewski, E. (1997). Polacy w Skandynawii. Lublin: PANTA.

Otok, S. (2002). Geografia polityczna: geopolityka, państwo, ekopolityka. Warszawa: PWN.

Petersen, W. (1958). A General Typology of Migration. American Sociological Review, 23, 256-266.

Pilch, A., Zgórniak, M. (1984). Emigracja po drugiej wojnie światowej.W: A. Pilcha (red.). Emigracja z ziem polskich w czasach nowożytnych i najnowszych. Warszawa, 484-487.

Piwnicki, G. (2007). Czynniki determinujące światową migrację w dobie zachodzących przemian globalizacyjnych przełomu XX i XXI wieku. W: E. Polak i J. Leska-Ślęzak (red.). Procesy migracyjne w kontekście przemian kulturowo-cywilizacyjnych. Pelplin: Uniwersytet im. Adama Mickiewicza w Poznaniu.

Pryor, R. (1975). Migration and The process of modernization. W: L. Kosiński, M. Prothero (red.). People on the move: Studies on internal migration. London.

Rajkiewicz, A. (red.). (2000). Zewnętrzne migracje zarobkowe we współczesnej Polsce. Wybrane zagadnienia. Włocławek: WSHE.

Romaniszyn, K. (2003). Kulturowe implikacje międzynarodowych migracji. Lublin: KUL. Romaniszyn, K. (1999). Światowe szlaki migracyjne: przemiany i kontynuacje. W: J.E. Zamojski (red.). Migracje 1945-1995. Warszawa: Neriton.

Richmond, A.H. (1994). Global Apartheid. Refugees, Racism and The New World Order. Refuge: Canada's Journal on Refugees, 14(6), 25-28.

Rykiel, Z. (2006). Podstawy geografii politycznej. Warszawa: Polskie Wydawnictwo Ekonomiczne.

Stępniak, A. (red.). (2001). Swobodny przepływ pracowników w kontekście wejścia Polski do Unii Europejskiej. Warszawa: Kancelaria Prezesa Rady Ministrów.

Sztompka, P. (2002). Socjologia. Analiza społeczeństwa. Kraków: Znak.

Szydłowska-Cegłowa, B. (red.). (1992). Polonia w Europie. Poznań: Polska Akademia Nauk.

Świętochowska, U. (2007). Problemy migracji w Unii Europejskie. W: E. Polak, J. Leska-Ślęzak (red.). Procesy migracyjne w kontekście przemian kulturowo-cywilizacyjnych. Pelplin: Uniwersytet im. Adama Mickiewicza w Poznaniu.

The Organization for Economic Co-operation and Development (OECD), Matching Educational Background and Employment: A Challenge for Immigrants In Host Countries. Pobrane z: https://www.oecd.org/migration/mig/41561786.pdf.

World Bank Group. (2018). Migration and Remittances, Recent Developments and Outlook. Pobrane z: http://documents.worldbank.org/curated/en/805161524552566695/ pdf/125632-WPPUBLICMigrationandDevelopmentBrief.

Zolberg, A.R. (1989). The Next Waves: Migration Theory for a Changing World. International Migration Review, 23(3), 403-430. 